\title{
Connexins and Disease
}

\author{
Mario Delmar, ${ }^{1}$ Dale W. Laird, ${ }^{2}$ Christian C. Naus, ${ }^{3}$ Morten S. Nielsen, ${ }^{4}$ Vytautas K. Verselis, ${ }^{5}$ \\ and Thomas W. White ${ }^{6}$ \\ ${ }^{1}$ The Leon H. Charney Division of Cardiology, New York University School of Medicine, New York, \\ New York 10016 \\ ${ }^{2}$ Department of Anatomy and Cell Biology, University of Western Ontario, London, Ontario N6A5C1, Canada \\ ${ }^{3}$ Department of Cellular and Physiological Sciences, University of British Columbia, Vancouver, British \\ Columbia V6T 1Z3, Canada \\ ${ }^{4}$ Department of Biological Sciences, Faculty of Health and Medical Sciences, University of Copenhagen, \\ Copenhagen 2200, Denmark \\ ${ }^{5}$ Dominick P. Purpura Department of Neuroscience, Albert Einstein College of Medicine, New York, \\ New York 10461 \\ ${ }^{6}$ Department of Physiology and Biophysics, Stony Brook University, Stony Brook, New York 11790 \\ Correspondence: mario.delmar@nyumc.org
}

Inherited or acquired alterations in the structure and function of connexin proteins have long been associated with disease. In the present work, we review current knowledge on the role of connexins in diseases associated with the heart, nervous system, cochlea, and skin, as well as cancer and pleiotropic syndromes such as oculodentodigital dysplasia (ODDD). Although incomplete by virtue of space and the extent of the topic, this review emphasizes the fact that connexin function is not only associated with gap junction channel formation. As such, both canonical and noncanonical functions of connexins are fundamental components in the pathophysiology of multiple connexin related disorders, many of them highly debilitating and life threatening. Improved understanding of connexin biology has the potential to advance our understanding of mechanisms, diagnosis, and treatment of disease.

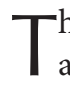
he demand for intercellular communication arose with the evolution of multicellular organisms and in vertebrates, direct communication occurs at aggregates of intercellular channels called gap junctions. The gap junctional channels are comprised of connexins, in which each connexin has four membrane spanning domains, two extracellular loops, one intracellular loop, and intracellular amino and carboxyl termini (for a general review on connexins, see Nielsen et al. 2012). Six connexins form a con- nexon or hemichannel that after trafficking to the plasmamembrane docks with a connexon from a neighboring cell and form an intercellular channel (see Fig. 1). Humans express 21 different connexion isoforms, each with its own distinct biophysical properties and expression pattern. Although all connexins form cell-cell channels, it has become clear that connexins also have functions that are unrelated to intercellular coupling. Undocked hemichannels can open and exchange substances or ions between

Editors: Carien M. Niessen and Alpha S. Yap

Additional Perspectives on Cell-Cell Junctions available at www.cshperspectives.org

Copyright (C) 2018 Cold Spring Harbor Laboratory Press; all rights reserved; doi: 10.1101/cshperspect.a029348

Cite this article as Cold Spring Harb Perspect Biol 2018;10:a029348 
M. Delmar et al.

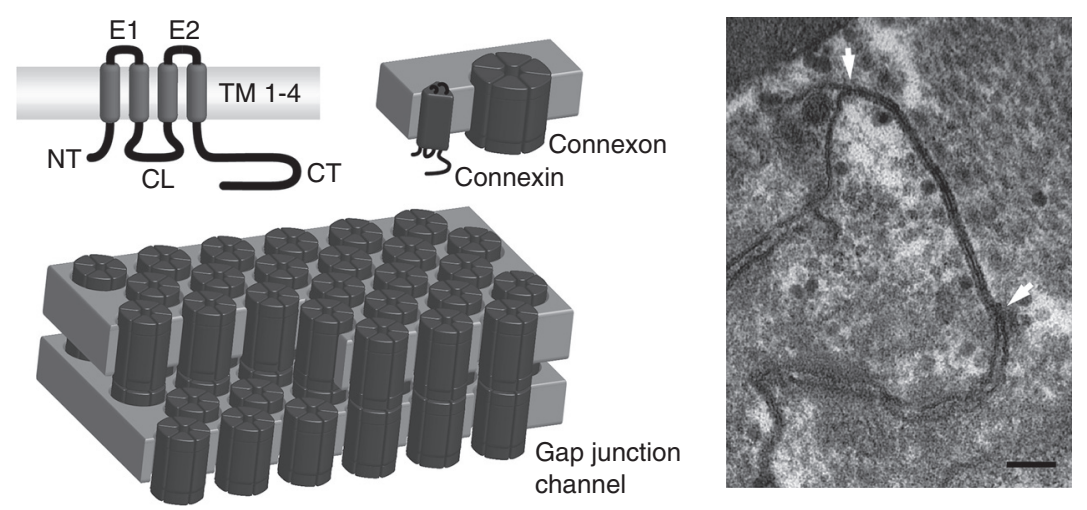

Figure 1. Connexin structure and organization. Connexins have four transmembrane domains (TM1-4), two extracellular loops (E1-2), a cytoplasmic loop (CL), and cytoplasmic amino and carboxyl termini (NT and CT). Six connexins oligomerize to form a connexon, also known as a hemichannel, which dock with a connexon from a neighboring cell to form an intercellular gap junctional channel. Gap junctional channels form densely packed plaques that appear as a pentalaminar structure in electron microscopy (EM) (between arrows in left panel). Scalebar, $100 \mathrm{~nm}$. (From Axelsen et al. 2013, reprinted, with permission, from the authors.)

the cytoplasm and the extracellular environment, which may exert signaling as well as pathophysiological functions (Nielsen et al. 2012). Furthermore, some connexins have channel-independent functions often associated with their ability to bind and organize cytoskeletal and signaling components (e.g., Cx43) (Leo-Macias et al. 2016a). Because connexins are expressed in most cells of the human body and exert multiple roles, their dysfunction is often associated with disease as summarized in Table 1. At this point, it seems pertinent to begin with a disclaimer. At this writing, the words "connexin" and "disease" bring close to two thousand articles in PubMed. We have attempted to reduce a large body of literature into a few pages and in doing so, we are for sure guilty of excluding many outstanding contributions that have moved the field forward. The present review touches on a limited number of diseases that may be representative of the gamet of morbidities that result from alterations in the structure and/or function of connexin proteins. We purposely chose to speak about "connexins and disease," rather than "gap junctions and disease." The former seeks to emphasize the fact that connexins are not only gap junction-forming proteins. There is a solid body of literature showing that membrane hemichannels can play a critical role in the ori- gin of disease. There is also emerging literature on the role of connexins as components of multimolecular complexes, whereby loss of connexin integrity can disrupt functions seemingly foreign to those classically ascribed to either gap junctions, or connexin hemichannels. Connexins do not live in silos, isolated from other components of the cellular landscape. In the end, many years of studies on multiple "monogenic" syndromes have taught us that most diseases, including the inheritable ones, result from the balance of function within multimolecular constellations. The same becomes apparent when one reviews the topic of connexins and disease.

\section{Cx43 IN OCULODENTODIGITAL DYSPLASIA}

The library of connexin-linked diseases has grown over the past two decades to include many rare syndromes and conditions. One of the best studied connexin-linked diseases is the multisystem development disorder known as oculodentodigital dysplasia (ODDD), which is now known to be caused by nearly 80 distinct mutations in the GJA1 gene encoding $\mathrm{Cx} 43$ (Paznekas et al. 2003, 2009; Laird 2014). Almost all ODDD patients have one normal GJA1 allele 
Table 1. Disease causing connexin mutations in humans

\begin{tabular}{|c|c|c|c|c|}
\hline Connexin & Gene & Disease name & Phenotype & Functional alterations \\
\hline $\mathrm{Cx} 26$ & GJB2 & $\begin{array}{l}\text { Deafness } \\
\text { PPK } \\
\text { KID }\end{array}$ & $\begin{array}{l}\text { Deafness } \\
\text { Skin disease and } \\
\text { deafness } \\
\text { Skin disease and } \\
\quad \text { deafness }\end{array}$ & $\begin{array}{l}\text { Loss of connexin expression } \\
\text { Gain of hemichannel function } \\
\text { Gain of hemichannel function }\end{array}$ \\
\hline $\mathrm{Cx} 30$ & GJB6 & $\begin{array}{l}\text { Deafness } \\
\text { HED }\end{array}$ & $\begin{array}{l}\text { Deafness } \\
\text { Skin disease }\end{array}$ & $\begin{array}{l}\text { Unknown } \\
\text { Gain of hemichannel function }\end{array}$ \\
\hline Cx30.3 & GJB4 & EKVP & Skin Disease & \\
\hline $\mathrm{Cx} 31$ & GJB3 & $\begin{array}{l}\text { EKVP } \\
\text { Deafness }\end{array}$ & $\begin{array}{l}\text { Skin disease } \\
\text { Deafness }\end{array}$ & Gain of hemichannel function \\
\hline $\mathrm{Cx} 32$ & GJB1 & CMTX1 & $\begin{array}{l}\text { Peripheral neuropathy } \\
\text { and occasional CNS } \\
\text { involvement }\end{array}$ & Loss of GJ channel function \\
\hline $\mathrm{Cx} 40$ & GJA5 & $\mathrm{AF}$ & Atrial fibrillation & $\begin{array}{l}\text { Loss of GJ channel function } \\
\text { Loss of proper GJ channel trafficking }\end{array}$ \\
\hline $\mathrm{Cx} 43$ & GJA1 & $\begin{array}{l}\text { ODDD } \\
\text { EKVP } \\
\text { PPK }\end{array}$ & $\begin{array}{l}\text { Multiple defects } \\
\text { depending on } \\
\text { mutation }\end{array}$ & $\begin{array}{l}\text { Loss of GJ channel function } \\
\text { Loss of proper GJ channel trafficking } \\
\text { Gain of hemichannel function } \\
\text { Trans-dominant effects on other connexins }\end{array}$ \\
\hline $\mathrm{Cx} 46$ & GJA3 & Cataract & Cataract & $\begin{array}{l}\text { Gain of hemichannel function } \\
\text { Loss of hemichannel function } \\
\text { Loss of GJ channel function }\end{array}$ \\
\hline $\mathrm{Cx} 47$ & GJC2 & $\begin{array}{l}\text { PMLD } \\
\text { LMPH1C }\end{array}$ & $\begin{array}{l}\text { Multiple CNS defects } \\
\text { lymphedema }\end{array}$ & $\begin{array}{l}\text { Loss of GJ channel function } \\
\text { Loss of proper GJ channel trafficking } \\
\text { Loss of hemichannel function } \\
\text { Nonchannel effects also likely }\end{array}$ \\
\hline Cx50 & GJA8 & Cataract & Cataract & $\begin{array}{l}\text { Gain of hemichannel function } \\
\text { Loss of hemichannel function } \\
\text { Loss of GJ channel function }\end{array}$ \\
\hline
\end{tabular}

For review on cataract causing mutations, see Berthoud and Ngezahayo (2017), otherwise see text for references.

PPK, palmoplantar keratoderma with deafness; KID, keratitis-ichtyosis-deafness syndrome; HED, hidrotic ectodermal dysplasia; EKVP, erythrokeratodermia variabilis et progressiva; CMTX1, Charcot-Marie-Tooth neuropathy X type 1; AF, atrial fibrillation; ODDD, oculodentodigital dysplasia; PMLD, Pelizaeus-Merzbacher-like disease; LMPH1C: hereditary lymphedema type IC

consistent with autosomal dominant inheritance of disease. Patients with ODDD typically have ocular defects including small eyes, dental abnormalities related to the loss of tooth enamel, soft tissue fusion of the fingers and toes, and skeletal defects particularly in craniofacial bones (Paznekas et al. 2003, 2009; Laird 2014). In addition to these common traits that are found in most ODDD patients, patients variably present with any number of comorbidities that include central nervous system (CNS) defects, bladder incontinence, skin disorders or more than a half-dozen other rare conditions (Paznekas et al. 2003, 2009; Laird 2014). Interestingly, for reasons that remain unclear, the health status of ODDD patients tends to worsen with age presumably because of changes in the CNS (De Bock et al. 2013a). The plethora of affected organs in ODDD is somewhat predictable given that $\mathrm{Cx} 43$ is highly expressed in most human tissues. What was less predicted is the finding that a $\mathrm{Cx} 43$-rich organ, like the heart, is most often disease-free in ODDD patients, raising questions as to the mechanisms involved (Laird 2014; Kelly et al. 2015). The most prevalent explanation for how the heart is exempt from disease in ODDD is rooted in compensatory mechanisms in which other members of the 21 
M. Delmar et al.

connexin family are expressed in the same cardiac cells that co-express Cx43. Alternatively, and as discussed in a later section of this review, some evidence supports the premise that the heart can tolerate massive reductions in $\mathrm{Cx} 43$ before disease becomes evident (Flenniken et al. 2005; Kalcheva et al. 2007; Dobrowolski et al. 2008).

Over the past decade, more than two dozen Cx43 mutants have been expressed and interrogated in either reference-cells or tissue-relevant cells to assess their trafficking, assembly, and functional status (Shibayama et al. 2005; Paznekas et al. 2009; De Bock et al. 2013a; Laird 2014). These studies were combined with discoveries from three genetically modified mouse models that mirrored ODDD, to elucidate the genotype relationship of ODDD mutants to phenotype outcomes as they translate to clinical symptoms in humans (Flenniken et al. 2005; Kalcheva et al. 2007; Dobrowolski et al. 2008). Collectively, these studies revealed that GJA1 gene mutations can cause ODDD by at least ten different mechanisms that can be subclassified as either loss-offunction or gain-of-function mutations (Kelly et al. 2015). Loss-of-function mutants include those that fail to properly traffic to the cell surface and are retained within compartments associated with protein secretion. Other mutants are still able to assemble structural gap junctions but the resulting channels are functionally dead. Gain-of-function mutants may traffic properly to the cell surface but assemble into hyperactive connexin "hemichannels." Still other mutants in this class interact inappropriately with co-expressed connexins and show aberrant transdominant effects on a broader range of connexin channels (De Bock et al. 2013a; Laird 2014). Studies from harvested patient dermal fibroblasts have further resolved the impact of ODDD-linked mutants in a more native environment, in which the mutant and endogenous Cx43 levels are appropriately balanced in this predominantly autosomal dominant disease (Churko et al. 2011; Esseltine et al. 2015). Even with increased knowledge of the genetic and mechanistic basis of ODDD, no treatments are available for ODDD other than surgical interventions such as digit separation surgeries.

\section{CONNEXINS IN CANCER}

The year 2016 marks the 50th anniversary of Loewenstein and Kanno's discovery that intercellular communication was absent in liver tumor cells (Loewenstein and Kanno 1966). Ensuing studies interrogating connexin and gap junction levels in a variety of tumor cell types and in vivo tumors were relatively consistent with connexins having tumor suppressive properties (Yamasaki et al. 1995; Mesnil 2002; Naus and Laird 2010). This position was supported by a diverse set of studies that reported restored growth control in tumor cells engineered to ectopically express connexins (Zhu et al. 1991; Naus et al. 1992). Other studies showed that tumor-promoting agents and cancer-causing viruses typically shutdown gap junctional intercellular communication (GJIC) in cells destined to be transformed (Crow et al. 1992). Probably the most compelling evidence linking connexins to tumorigenesis was from findings in genetically modified mice that either lacked a connexin or expressed a loss-of-function connexin mutant. For instance, mice lacking $\mathrm{Cx} 32$ were much more susceptible to chemical- or radiation-induced liver and/or lung tumors whereas mice expressing a Cx43 loss-of-function mutant in an ErbB2 overexpressing background had increased mammary gland tumor metastasis to the lungs (Temme et al. 1997; King and Lampe 2004a,b; Plante et al. 2011).

Over the past two decades, strategic studies have revealed that the role of connexins and gap junctions in cancer is much more complex than originally proposed. First, more exhaustive analyses of tumor types in situ and of stages of disease have revealed that some tumors are connexin-rich, and that high connexin-expression in metastatic disease may even be a negative prognostic indicator (Ito et al. 2000; Naus and Laird 2010; Zhang et al. 2015). Second, the mechanism by which connexins act in tumor cells is not limited to GJIC; in fact, several studies support a GJIC-independent action of connexins mediated through connexin "hemichannels" or the connexin interactome (Krutovskikh et al. 2000; McLachlan et al. 2006; Zhang et al. 2014). Third, the large 21 member connexin 
family has potentially diverse roles in cancers as some connexins may show tumor suppressive properties in some tumor types whereas a second connexin subtype may provide no benefit (Yu et al. 2014; Yang et al. 2015). This outcome may be rooted in a naïve understanding of what passes through each connexin channel type in vivo. Lastly, epidemiological studies linking the functional status of connexins to cancer onset and disease progression is still lacking. For instance, there are hundreds-of-thousands of patients worldwide that have severely impaired Cx26 function, which typically manifests as hearing loss (Chan and Chang 2014), but there are no known reports that these patients are at increased risk for cancer in organs that are rich in Cx26, such as the liver.

Going forward, the question remains as to whether connexins are a viable target in cancer prevention or treatment. At present, although connexins are currently being targeted in clinical trials to stimulate and accelerate chronic wound repair (Becker et al. 2016), no trials targeting connexins in cancer have been initiated. In fact, although evidence suggests connexin upregulation or functional activity may be beneficial to reduce cancer onset and primary tumor growth, complexing evidence suggest that some connexins may provide the tumor with an advantage in metastatic disease. Therefore, caution must be exercised when considering targeting connexins in cancer. Nevertheless, as genotyping patient tumors becomes more routine, it is possible to imagine where it is beneficial to target connexins in a subset of tumors as part of a combinatorial treatment program.

\section{CONNEXINS AND NEUROLOGICAL DISORDERS}

The nervous system is comprised of multiple cell types arrayed in complex interconnections. One way these various cell types interact and communicate is through gap junctions related to their functional roles (Decrock et al. 2015). Distinct connexins are expressed in unique cell types in the peripheral nervous system (PNS) and CNS; the specificity of this expression underlies the critical roles of each of these cells in neurological functions. It is thus not surprising that the nervous system expresses up to 12 of the 21 connexin family members.

Within the mammalian PNS, gap junctions are primarily associated with the myelinating Schwann cells. Here, Cx32 forms reflexive gap junctions between the myelin lamellae connecting the Schwann cell cytoplasm with the adaxonal cell compartment inside the myelin sheath. This arrangement allows for diffusion of ions and small molecules across the apposed cell membranes comprising the myelin sheath. Cx32 forming these gap junctions thus plays a critical role in the homeostasis of myelinated axons. Indeed, this essential function of $\mathrm{Cx} 32 \mathrm{ac}$ counts for the pathology seen in the first reported human connexin disease, namely Charcot-Marie-Tooth neuropathy X type 1 (CMTX1), a progressive peripheral neuropathy characterized by a mixed pathology of demyelination and axonal degeneration (Bergoffen et al. 1993). With more than 400 different mutations in the GJB1 gene encoding Cx32, CMTX1 is the second most common form of CMT (Kleopa and Sargiannidou 2015). Both in vitro and in vivo models of the disease indicate that most $\mathrm{Cx} 32$ mutations give rise to an inability of the mutant $\mathrm{Cx} 32$ to form functional gap junctions (Kleopa et al. 2012).

Within the mammalian CNS, various cell types express more than 10 different connexins, reflecting the complexity and diverse network of intercellular communication. These channels have distinct functions within the different cell types and their expression can change dramatically during neurodevelopment (Cina et al. 2007) and injury (Freitas-Andrade and Naus 2016). To date, three of these genes, GJB1 (Cx32), GJC2 (Cx47), and GJA1 (Cx43), when mutated are associated with CNS disorders (Abrams and Scherer 2012).

The main connexins expressed in the CNS are Cx43 and Cx30 (Nagy et al. 1999); both are highly expressed in astrocytes. To a lesser extent, astrocytic Cx26 has also been reported (Nagy et al. 2001). Within these cells, gap junctions form a functional syncytium of coupled astrocytes, contributing to extracellular homeostasis through spatial buffering (Scemes and Spray 2012). Astrocytic Cx43 has been shown to un- 
M. Delmar et al.

derlie gap junctions functioning to spatially buffer $\mathrm{K}^{+}$and glutamate (Wallraff et al. 2006; Giaume et al. 2010), whereas Cx30 modulates astrocyte glutamate transport and morphology of astrocytic processes at the synaptic cleft, thereby controlling hippocampal excitatory synaptic transmission (Pannasch et al. 2014). Substantial evidence has implicated Cx43 in neuroprotection in models of ischemic and neurodegenerative conditions (Decrock et al. 2015; Freitas-Andrade and Naus 2016). In the context of human mutations of the GJA1, these are associated with the previously mentioned ODDD (Paznekas et al. 2003; Huang et al. 2013), a disorder that can also display CNS issues (Loddenkemper et al. 2002; Abrams and Scherer 2012) as discussed in the paragraphs above.

Oligodendrocytes express several connexins (Cx32, Cx29/31.1, Cx47), which have been shown to be necessary for proper myelination (Menichella et al. 2003), as well as potassium buffering (Menichella et al. 2006). Loss of both $\mathrm{Cx} 32$ and $\mathrm{Cx} 47$ in the CNS causes severe demyelination in mice (Menichella et al. 2003; Odermatt et al. 2003). Therefore, it was not surprising that loss-of-function mutations in GJC2 encoding Cx47 in humans causes Pelizeaus-Merzbacher-like disease, a severe hypomyelinating leukodystrophy (Uhlenberg et al. 2004). Mutations in GJB1, encoding Cx32, can also result in CNS symptoms (Abrams and Scherer 2012).

Microglia constitutes the innate immune system of the CNS. The literature reports conflicting findings as to which connexins are present in microglia, but these discrepancies most likely arise as a result of different states of microglial activation (Gajardo-Gomez et al. 2016). The microglia have been reported to express $\mathrm{Cx} 43$ and form gap junctions (Eugenin et al. 2001), whereas other studies have not observed $\mathrm{Cx} 43$ immunoreactivity in microglia (Mei et al. 2010; Theodoric et al. 2012). Furthermore, Cx43 has been shown to not form gap junctions in microglia (Wasseff and Scherer 2014), but rather form hemichannels (Takeuchi et al. 2006). Expression of other connexins in microglia has also been described, including Cx32 (Dobrenis et al. 2005; Maezawa and Jin 2010),
Cx36 (Dobrenis et al. 2005), and Cx29 (Moon et al. 2010). Microglia thus appear to be very dynamic in their connexin expression profile.

The vascular cells in the CNS express several connexins (Cx37, Cx40, Cx43), which contribute to interendothelial coupling, as well as heterocellular coupling with astrocytes (De Bock et al. 2011, 2013b; Ransom and Giaume 2012). These play an important role in determining astrocyte and endothelial contributions to the blood brain barrier (BBB) (De Bock et al. 2014). This has been shown using $\mathrm{Cx} 43 / \mathrm{Cx} 30$ double knockout mice (Ezan et al. 2012). These mice show a compromised BBB function under stress caused by increased hydrostatic vascular pressure and shear stress, swelling of astrocytic endfeet caused by edema, as well as reduced expression of aquaporin- 4 and $\beta$-dystroglycan, involved in anchoring astrocyte endfeet to the perivascular basal lamina. Endothelial functions are closely regulated by junctional interactions with astrocytes; specifically important are the connexins expressed in astrocytic endfeet (Froger et al. 2010; Pannasch et al. 2011).

Depending on the maturity of the CNS, neurons can express several different connexins, including Cx36 (Belluardo et al. 2000; Venance et al. 2000; Rash et al. 2012), Cx30.2 (i.e., human Cx31.9) (Kreuzberg et al. 2008), Cx31.1 (Dere et al. 2008), Cx40 (Personius et al. 2007), and Cx45 (Li et al. 2008). This presumably reflects not only the diversity of neuronal cell types, but also varying functions in the developing CNS. Knockout (Fushiki et al. 2003; Cina et al. 2009) and knockdown (Elias et al. 2007) of Cx43 disrupts neuronal migration in the developing mouse brain, implying a possible role for gap junctions in neurodevelopmental disorders. Knockout of Cx36 in mice results in near complete loss of neuronal gap junctions in the mature CNS (Deans et al. 2001; Hormuzdi et al. 2001; Long et al. 2002; De Zeeuw et al. 2003). Surprisingly, the phenotype of these mice is rather mild, and includes loss of synchronous inhibitory activity in the hippocampus (Deans et al. 2001) and visual defects in the rod pathway (Guldenagel et al. 2001). No human mutations of the GJD2 gene encoding Cx36 have been reported. 


\section{SKIN DISEASES AND CONNEXINS}

Eleven clinically defined skin diseases with overlapping phenotypes are caused by mutations in five distinct connexin genes (Lilly et al. 2016). Six of these disorders are caused by mutations in GJB2, causing a majority of the functional research to focus on Cx26. The preponderance of evidence suggests that the skin diseases caused by connexin mutations are a result of dominant gains-of-function. In palmoplantar keratoderma with deafness (PPK), the Cx26 mutations modify the function of wild-type Cx43, resulting in leaky heteromeric hemichannels (Shuja et al. 2016). In KID keratitis-ichtyosis-deafness (KID) syndrome, Cx26 mutations form active hemichannels with in creased calcium permeability, or altered regulation by calcium, voltage, and $\mathrm{pH}$ (Lee and White 2009; Sanchez and Verselis 2014; Sanchez et al. 2014, 2016). A detailed understanding of these subtle functional differences will be necessary to develop mechanistic-based therapies for connexin-related skin diseases.

The five connexins linked to skin disease have overlapping patterns of expression. In normal adult human skin, $\mathrm{Cx} 26$ is restricted to basal keratinocytes in palmoplantar skin, whereas $\mathrm{Cx} 43$ is expressed in all epidermal layers. Cx26 and $\mathrm{Cx} 43$ are also present in sweat glands and hair follicles. In contrast, $\mathrm{Cx} 30, \mathrm{Cx} 30.3$, and $\mathrm{C} \times 31$ are only expressed in the upper differentiated epidermal layers (Salomon et al. 1994; Di et al. 2001). A large induction of Cx26 expression is observed across the epidermis in human skin after wounding, or other pathological and experimental changes in skin thickness (Rivas et al. 1997; Labarthe et al. 1998; Lucke et al. 1999; Rouan et al. 2001), which could have profound consequences on pathology caused by dominant gain-of-function mechanisms following Cx26 mutation.

Recent studies have begun to elucidate how increased hemichannel activity could contribute to changes in epidermal homeostasis associated with the connexin genodermatoses. Hemichannels form aqueous pores, allowing inorganic ions and metabolites to pass between the cytoplasm and extracellular space. Electrophysiolog- ical studies using cysteine scanning revealed that many of the residues mutated in KID syndrome lined the hemichannel pore, and that calcium regulation of the hemichannels differed. Some of the KID mutations become insensitive to inhibition of hemichannel activity by extracellular $\mathrm{Ca}^{2+}$, whereas others showed only modest impairment in $\mathrm{Ca}^{2+}$ gating. However, mutant hemichannels with modestly impaired gating showed a substantially increased permeability to $\mathrm{Ca}^{2+}$ (Sanchez et al. 2010, 2013, 2016). Thus, KID syndrome mutations all show hemichannel gain-of-function that produce epidermal pathology, but through different mechanisms, potentially explaining the phenotypic heterogeneity among patients carrying different mutations. The epidermis maintains an extracellular calcium gradient, with the highest levels in the granular layer and an abrupt reduction in the cornified layer, and calcium is a key regulator of keratinocyte differentiation (Elsholz et al. 2014). The altered $\mathrm{Ca}^{2+}$ permeation properties of KID hemichannels would almost certainly disrupt this gradient and affect keratinocyte differentiation. Additional studies using mouse models of KID syndrome have provided further support for mutant hemichannels disrupting calcium homeostasis in vivo. Transgenic mice expressing KID develop epidermal pathology, and increased hemichannel activity was detected in primary keratinocytes isolated from KID lesions (Mese et al. 2011; Schutz et al. 2011). When the epidermal calcium gradient was examined in the skin of these mice, it was found to be elevated in both the intra- and extracellular compartments of the cornified layer. This change in $\mathrm{Ca}^{2+}$ homeostasis was associated with defects in the epidermal water barrier and altered lipid secretion in the affected skin (Bosen et al. 2015).

Increased hemichannel activity has been compellingly linked to specific Cx26 mutations causing KID syndrome, raising the question as to whether there may be a generalized role for dysregulated hemichannels in some of the other connexin skin disorders. Evidence that altered hemichannel function may also play a role in other connexin genodermatoses comes from studies of $\mathrm{Cx} 30$ mutations associated with hidrotic ectodermal dysplasia (HED). Expression 
M. Delmar et al.

of these mutants in vitro caused cell death that was correlated with large voltage-activated currents in cells expressing mutant proteins. In addition, cells expressing the mutant connexins had a much higher rate of ATP leakage than controls, suggesting that hemichannel-mediated ATP release may contribute to HED syndrome pathology (Essenfelder et al. 2004). In a similar fashion, Cx31 mutations linked to erythrokeratodermia variabilis et progressiva (EKVP) and Cx43 mutations causing keratoderma-hypotrichosis-leukonychia totalis syndrome (KHLT) were both shown to result in increased hemichannel activity, $\mathrm{Ca}^{2+}$, or ATP leakage, and cell death when expressed in transfected cells (Chi et al. 2012; Wang et al. 2015).

A growing body of evidence suggests that many, if not a majority, of the connexin mutations associated with distinct skin diseases consistently acquire unique gain-of-function activities. So far, the most prominent mechanism is the formation of dysregulated hemichannels that either increase ATP leakage, or disrupt $\mathrm{Ca}^{2+}$ homeostasis within keratinocytes and in the extracellular gradient. Further study of disease-causing mutations coupled with additional analysis of transgenic mice expressing them in native epidermis will continue to provide new mechanistic insight into the pathophysiology of the connexin genodermatoses.

\section{CONNEXINS AND DEAFNESS}

One of the most common causes of autosomal recessive, nonsyndromic, sensorineural deafness is mutation of the GJB2 gene encoding the Cx26 gap junction (GJ) protein. Remarkably, although mutations in more than 90 genes have been identified that are associated with deafness, Cx26 mutations account for as much as $50 \%$ of hearing loss characterized as severe to profound. $\mathrm{Mu}$ tations in the GJB6 gene encoding Cx30 also cause deafness, but are much less frequent.

In addition to forming GJ channels that signal between cells, Cxs can function as undocked hemichannels that signal across the plasma membrane, as outlined in the introduction. In the cochlea, Cx26 and Cx30 are expressed in the supporting cells of the organ of Corti surround- ing the sensory hair cells as well as in the lateral wall containing the stria vascularis (Lautermann et al. 1998; Ahmad et al. 2003; Forge et al. 2003; Zhao and Yu 2006; Liu and Zhao 2008). The stria vascularis is responsible for producing endolymph and generating the endocochlear potential, EP, which is critical for proper signal transduction in hair cells. Both Cxs show widely overlapping patterns of expression and an abundance of GJs indicative of extensive interconnected cellular networks. There is also surface expression of $\mathrm{Cx} 26$ in basolateral and apical regions of supporting cells in regions devoid of cell-cell contacts, indicating the presence of hemichannels that can communicate with perilymphatic and endolymphatic compartments (Majumder et al. 2010).

The majority of nonsyndromic Cx26 mutations are deletions, truncations, and frameshifts indicating that loss of GJ and/or hemichannel function results in hearing loss. However, there are a number of dominant, missense mutations that produce functional channels and result in syndromes in which hearing loss is accompanied by severe skin disorders, such as KID syndrome (reviewed above) (Lee and White 2009; $\mathrm{Xu}$ and Nicholson 2013).

Studies of Cx26 knockout (KO) mice and transgenics with dominant-negative activity are in general agreement that loss of $\mathrm{Cx} 26$ channel function, even when restricted to supporting cells in the sensory epithelium, produces deafness and leads to eventual death of supporting cells and hair cells (Cohen-Salmon et al. 2002; Kudo et al. 2003; Maeda et al. 2007; Sun et al. 2009). Reports of hearing loss before evidence of cell death or rundown of the EP have suggested a role for Cx26 in the developing cochlea (Wang et al. 2009; Liang et al. 2012; Chen et al. 2014). Knockout of Cx30 in mice was also reported to cause deafness with rundown of the EP (Teubner et al. 2003; Schutz et al. 2010). However, expression of $\mathrm{Cx} 26$ was shown to decrease in the cochleae of Cx30 null mice (Ahmad et al. 2007; Ortolano et al. 2008) and when Cx26 expression was preserved or increased in Cx30null mice, hearing loss was prevented (Ahmad et al. 2007; Boulay et al. 2013). Increasing Cx30 expression in Cx26 null mice did not prevent 
hearing loss (Qu et al. 2012). Thus, the presence of $\mathrm{Cx} 26$, but not $\mathrm{Cx} 30$ channels in the sensory epithelium is crucial for hearing, whereas either $\mathrm{Cx} 26$ or $\mathrm{Cx} 30$ in the stria vascularis appears capable of maintaining hearing.

Mechanistically, although GJs in the stria vascularis are undoubtedly important for $\mathrm{K}^{+}$ transport and maintenance of the $\mathrm{EP}$, a role for GJs in $\mathrm{K}^{+}$transport within the sensory epithelium is not supported (Cohen-Salmon et al. 2002; Kudo et al. 2003; Wangemann 2006; Zdebik et al. 2009; Patuzzi 2011). Rather, GJs likely communicate nutrients and signaling molecules, as shown for glucose and inositol triphosphate $\left(\mathrm{IP}_{3}\right)$, which presumably maintain sensory epithelial integrity and aid in proper hair cell function (Beltramello et al. 2005; Zhang et al. 2005; Chang et al. 2008, 2009).

Hearing loss in syndromic deafness likely differs from the nonsyndromic form with mutant hemichannels that are overactive and/or show altered $\mathrm{Ca}^{2+}$ permeability leading to cell dysfunction and death (Stong et al. 2006; Gerido et al. 2007; Mese et al. 2008; Lee et al. 2009; Sanchez et al. 2010, 2013, 2014, 2016; Terrinoni et al. 2010; Levit et al. 2011, 2011; Mhaske et al. 2013; Garcia et al. 2015). For a number of syndromic deafness mutants, overactive hemichannels have been shown to be a consequence of weakened inhibition by extracellular divalent cations, particularly $\mathrm{Ca}^{2+}$ and by $\mathrm{pH}$ (Gerido et al. 2007; Lee et al. 2009; Sanchez et al. 2010, 2013, 2014, 2016; Levit et al. 2011; Mhaske et al. 2013). These mutant hemichannels can cause excessive membrane depolarization and initiate damaging membrane signaling. Altered permeability can also lead to damaging membrane signaling as suggested for the G45E KID syndrome mutation that is characterized by enhanced $\mathrm{Ca}^{2+}$ permeability (Sanchez et al. 2010). Patients carrying this mutation show profound deafness corroborated by brainstem audiometry (Gilliam and Williams 2002; Janecke et al. 2005; Griffith et al. 2006). An autopsy of a G45E patient showed widespread vestibulo-cochlear dysplasia in the organ of Corti with no evidence of a developed sensory epithelium (Griffith et al. 2006), plausibly explained by excessive $\mathrm{Ca}^{2+}$ entry and cell death during cochlear development. Corre- lates between patient phenotype and aberrant hemichannel function are emerging and their identification should shed light on the roles connexins play in cochlear function and provide avenues for treatment.

\section{CONNEXINS AND HEART DISEASE}

Cardiac cells mainly contain the connexins $\mathrm{Cx} 43>\mathrm{Cx} 40>\mathrm{Cx} 45>\mathrm{Cx} 31.9$ (please note that human Cx31.9 is the homolog of mouse Cx30.2) with Cx43 being the overall dominating and the sole gap junction protein in the ventricular myocardium. Gap junctions have been suggested to play a role in a number of cardiac pathologies, causing both electrical and structural disturbances.

Early observations showed that acute ischemia caused an increase in tissue resistivity, most likely by uncoupling of gap junctions (Wojtczak 1979; Kleber et al. 1987), and uncoupling correlated with the appearance of arrhythmia (Smith et al. 1995). Acute uncoupling occurs with a time course similar to that of intracellular acidosis and increased calcium (Carmeliet 1999), conditions that are known to close $\mathrm{Cx} 43$ gap junction channels (Burt 1987; Firek and Weingart 1995; Morley et al. 1996); but in addition to direct chemical gating, changes in $\mathrm{Cx} 43$ phosphorylation (Beardslee et al. 2000; Axelsen et al. 2006; Lampe et al. 2006) and lipid metabolites (Fluri et al. 1990; Hofgaard et al. 2008; Mollerup et al. 2011) may also contribute. Evidence suggests that uncoupling makes hearts more prone to reentrant arrhythmias, based on studies using pharmacological uncoupling (Ohara et al. 2002), prevention of uncoupling (Xing et al. 2003; Lewandowski et al. 2008), and genetic ablation of Cx43 (Danik et al. 2004). At least in some studies, ablation of $\mathrm{Cx} 40$ lowers atrial conduction velocity and increases atrial fibrillation (AF) risk (Hagendorff et al. 1999; Verheule et al. 1999; Bagwe et al. 2005), aligning well with studies linking Cx40 mutations and AF in humans (Gollob et al. 2006), of which at least one mutation replicates the phenotype when expressed in mice (Lubkemeier et al. 2013a). More recently, a mutation in $\mathrm{Cx} 43$ has also been linked to $\mathrm{AF}$ (Sinner et al. 2014). 
M. Delmar et al.

Gap junctions are not only involved in electrical abnormalities but also in determining infarct size after ischemia. Uncoupling was originally suggested to have beneficial effects by preventing spread of tissue damage. In support of this notion, chemical uncoupling reduces infarct size in animal models as first described by Garcia-Dorado and coworkers (1997). Although based on rather nonspecific inhibitors, these observations were initially a strong argument against the development of anti-arrhythmic therapies aimed at keeping gap junctions open. Using anti-arrhythmic peptides (rotigaptide and danegaptide) to keep gap junctions open, however, decreased rather than increased infarct size (Haugan et al. 2006; Hennan et al. 2006; Skyschally et al. 2013). The issue of the relation between gap junction availability and cardiac homeostasis extends not only to whether a gap junction channel is present, but also to whether those channels can be regulated by the intraceullular milieu. For example, infarct size was increased in mice expressing carboxyterminal truncated $\mathrm{Cx} 43$, which does not respond to $\mathrm{pH}$ and calcium induced gating (Maass et al. 2009). Furthermore, reducing Cx43 to 50\% by genetic ablation did not alter infarct size in mice (Schwanke et al. 2002). In contrast, preconditioning was lost in the $\mathrm{Cx} 43^{+/-}$mice (Schwanke et al. 2002) independent of an effect on intercellular coupling ( $\mathrm{Li}$ et al. 2004), an observation that led to the somewhat surprising discovery that $\mathrm{Cx} 43$ locates to mitochondria and protects them from ischemic damage (Boengler et al. 2005). This observation adds to a growing list of coupling-independent effects of connexins, as discussed below.

Following ischemia, gap junctions distribute heterogeneously with lateralization in the infarct border zone and these areas of disarray also display reentrant arrhythmias on local stimulation (Peters et al. 1997). Similar disarray is observed under several pathological conditions including heart failure (Kostin et al. 2003), systemic (Kostin et al. 2004), and pulmonary (Chkourko et al. 2012) hypertension; and although it is often assumed that lateralized gap junctions are not functional, a study suggests that they are (Cabo et al. 2006). The issue of lateralization of con- nexins and their impact on cardiac electrophysiology remains unclear.

Recent evidence shows that connexins have functions unrelated to intercellular coupling, and likely consequent to the fact that connexins are components of a protein interacting network (a "connexome") that includes molecules classically defined as belonging to mechanical junctions and to the voltage-gated sodium channel complex (Agullo-Pascual et al. 2014a,b). As a component of the connexome, Cx43 actually helps organize the microtubular network (Francis et al. 2011; Agullo-Pascual et al. 2013a,b). In fact, mislocalization of $\mathrm{Cx} 43$ can alter the trafficking of other proteins; along those lines, knocking $\mathrm{Cx} 43$ out in mice reduces the cardiac sodium current and contributes to arrhythmia susceptibility (Jansen et al. 2012). Knockdown of Cx43, removal of the carboxyl terminus, or of the tubulin binding domain also reduced the surface expression of NaV1.5 in HL-1 cells (Agullo-Pascual et al. 2014b). Similarly, removal of the PDZ-binding domain of Cx43 led to decreased sodium current and lethal arrhythmias (Lubkemeier et al. 2013b). Conversely, treating hearts injured by cryo-ablation with a peptide containing the carboxy-terminal PDZ-binding domain improved $\mathrm{Cx} 43$ localization and reduced arrhythmia burden (O'Quinn et al. 2011). Electrophysiological recordings indicated that conduction velocity was increased, but to what extent this finding could be explained by preservation of sodium current, was not tested.

The role of the gap junction plaque on action potential propagation may extend beyond the formation of the gap junction channel per se. In recent years, the concept of ephaptic or electrical field-mediated propagation has reemerged, placing the ephaptic phase as peripheral to the gap junction (in the "perinexus" as defined by the Gourdie laboratory (Rhett et al. 2011). Ephaptic coupling occurs when influx of sodium leads to a local extracellular negative potential, which effectively depolarizes the opposing membrane. Conditions for this to occur are predominantly a large and dense sodium current, and closely positioned membranes (Sperelakis 2002). These conditions are possibly met at the intercalated disc. In addition to the 
perinexus (Rhett et al. 2012), sodium channels are confronted against each other at the adhesion/excitability nodes, "mini-nodes of Ranvier" where clusters of $\mathrm{N}$-cadherin organize sodium channels into dense clusters (Leo-Macias et al. 2016b). Evidence for ephaptic coupling includes the finding that extracellular edema, contrary to expectation from cable theory, decreases rather than increases CV (Veeraraghavan et al. 2012). Ephaptic theory may also explain the paradox that in heterozygous $\mathrm{Cx} 43^{+/-}$mice, reduction of connexin abundance does not associate with changes in conduction velocity (Morley et al. 1999; Stein et al. 2009).

\section{CONCLUDING REMARKS}

Limitations in pharmacological tools and in methods for studying connexin function in vivo initially made it difficult to directly link connexin function to disease. It is $\sim 30$ years since the identification of the genes coding for gap junction proteins, which enabled us to link connexins to specific functions by the discovery of disease-causing mutations. In some cases, mutations confirmed our understanding of connexins as gap junctional channels that provide intercellular coupling, but in other cases, new noncanonical functions have emerged. The combined genetic and functional investigations have led to enormous leaps in understanding not only the function of these proteins but also their role in inherited and in acquired diseases. In both cases, we have learned that rarely is a disease caused by a single molecule, without the complicity of its neighbors. Phenotypes are the reflection of a constellation of molecules that work together, or fail to do so. Among the many challenges ahead is to gain a better understanding of how these constellations are formed, and how connexins operate within them so that we can better connect the two poles of a spectrum: connexin and disease.

\section{REFERENCES}

Abrams CK, Scherer SS. 2012. Gap junctions in inherited human disorders of the central nervous system. Biochim Biophys Acta 1818: 2030-2047.
Agullo-Pascual E, Lin X, Pfenniger A, Lubkemeier I, Willecke K, Rothenberg E, Delmar M. 2013a. A novel noncanonical role of cx43 in the heart: Ensuring the arrival of $\mathrm{Na}_{\mathrm{v}} 1.5$ to the intercalated disk. Heart Rhythm 10: 1742.

Agullo-Pascual E, Reid DA, Keegan S, Sidhu M, Fenyo D, Rothenberg E, Delmar M. 2013b. Super-resolution fluorescence microscopy of the cardiac connexome reveals plakophilin-2 inside the connexin 43 plaque. Cardiovasc Res 100: 231-240.

Agullo-Pascual E, Cerrone M, Delmar M. 2014a. Arrhythmogenic cardiomyopathy and Brugada syndrome: Diseases of the connexome. FEBS Lett 588: 1322-1330.

Agullo-Pascual E, Lin X, Leo-Macias A, Zhang M, Liang FX, Li Z, Pfenniger A, Lubkemeier I, Keegan S, Fenyo D, et al. $2014 \mathrm{~b}$. Super-resolution imaging reveals that loss of the C-terminus of connexin43 limits microtubule plus-end capture and $\mathrm{Na}_{\mathrm{V}} 1.5$ localization at the intercalated disc Cardiovasc Res 104: 371-381.

Ahmad S, Chen S, Sun J, Lin X. 2003. Connexins 26 and 30 are co-assembled to form gap junctions in the cochlea of mice. Biochem Biophys Res Commun 307: 362-368.

Ahmad S, Tang W, Chang Q, Qu Y, Hibshman J, Li Y, Sohl G, Willecke K, Chen P, Lin X. 2007. Restoration of connexin 26 protein level in the cochlea completely rescues hearing in a mouse model of human connexin30-linked deafness. Proc Natl Acad Sci 104: 1337-1341.

Axelsen LN, Stahlhut M, Mohammed S, Larsen BD, Nielsen MS, Holstein-Rathlou NH, Andersen S, Jensen ON, Hennan JK, Kjolbye AL. 2006. Identification of ischemia-regulated phosphorylation sites in connexin43: A possible target for the antiarrhythmic peptide analogue rotigaptide (ZP123). J Mol Cell Cardiol 40: 790-798.

Axelsen LN, Calloe K, Holstein-Rathlou NH, Nielsen MS. 2013. Managing the complexity of communication: Regulation of gap junctions by post-translational modification. Front Pharmacol 4: 130.

Bagwe S, Berenfeld O, Vaidya D, Morley GE, Jalife J. 2005. Altered right atrial excitation and propagation in connexin40 knockout mice. Circulation 112: 2245-2253.

Beardslee MA, Lerner DL, Tadros PN, Laing JG, Beyer EC, Yamada KA, Kleber AG, Schuessler RB, Saffitz JE. 2000. Dephosphorylation and intracellular redistribution of ventricular connexin43 during electrical uncoupling induced by ischemia. Circ Res 87: 656-662.

Becker DL, Phillips AR, Duft BJ, Kim Y, Green CR. 2016. Translating connexin biology into therapeutics. Semin Cell Dev Biol 50: 49-58.

Belluardo N, Mudo G, Trovato-Salinaro A, Le Gurun S, Charollais A, Serre-Beinier V, Amato G, Haefliger JA, Meda P, Condorelli DF. 2000. Expression of connexin 36 in the adult and developing rat brain. Brain Res 865: 121138.

Beltramello M, Piazza V, Bukauskas FF, Pozzan T, Mammano F. 2005. Impaired permeability to $\operatorname{Ins}(1,4,5) \mathrm{P} 3$ in a mutant connexin underlies recessive hereditary deafness. Nat Cell Biol 7: 63-69.

Bergoffen J, Scherer SS, Wang S, Scott MO, Bone LJ, Paul DL, Chen K, Lensch MW, Chance PF, Fischbeck KH. 1993. Connexin mutations in X-linked Charcot-Marie-Tooth disease. Science 262: 2039-2042.

Berthoud VM, Ngezahayo A. 2017. Focus on lens connexins. BMC Cell Biol 18: 6. 
M. Delmar et al.

Boengler K, Dodoni G, Rodriguez-Sinovas A, Cabestrero A, Ruiz-Meana M, Gres P, Konietzka I, Lopez-Iglesias C, Garcia-Dorado D, Di Lisa F, et al. 2005. Connexin 43 in cardiomyocyte mitochondria and its increase by ischemic preconditioning. Cardiovasc Res 67: 234-244.

Bosen F, Celli A, Crumrine D, Vom Dorp K, Ebel P, Jastrow $\mathrm{H}$, Dormann P, Winterhager E, Mauro T, Willecke K. 2015. Altered epidermal lipid processing and calcium distribution in the KID syndrome mouse model Cx26S17F FEBS Lett 589: 1904-1910.

Boulay AC, del Castillo FJ, Giraudet F, Hamard G, Giaume C, Petit C, Avan P, Cohen-Salmon M. 2013. Hearing is normal without connexin30. J Neurosci 33: 430-434.

Burt JM. 1987. Block of intercellular communication: Interaction of intracellular $\mathrm{H}^{+}$and $\mathrm{Ca}^{2+}$. Am J Physiol 253: C607-C612.

Cabo C, Yao J, Boyden PA, Chen S, Hussain W, Duffy HS, Ciaccio EJ, Peters NS, Wit AL. 2006. Heterogeneous gap junction remodeling in reentrant circuits in the epicardial border zone of the healing canine infarct. Cardiovasc Res 72: 241-249.

Carmeliet E. 1999. Cardiac ionic currents and acute ischemia: From channels to arrhythmias. Physiol Rev 79: $917-$ 1017.

Chan DK, Chang KW. 2014. GJB2-associated hearing loss: Systematic review of worldwide prevalence, genotype, and auditory phenotype. Laryngoscope 124: E34-E53.

Chang Q, Tang W, Ahmad S, Zhou B, Lin X. 2008. Gap junction mediated intercellular metabolite transfer in the cochlea is compromised in connexin 30 null mice. PLOS ONE 3: e4088.

Chang Q, Tang W, Ahmad S, Stong B, Leu G, Lin X. 2009. Functional studies reveal new mechanisms for deafness caused by connexin mutations. Otol Neurotol 30: 237240.

Chen S, Sun Y, Lin X, Kong W. 2014. Down regulated connexin26 at different postnatal stage displayed different types of cellular degeneration and formation of organ of Corti. Biochem Biophys Res Commun 445: 71-77.

Chi J, Li L, Liu M, Tan J, Tang C, Pan Q, Wang D, Zhang Z. 2012. Pathogenic connexin-31 forms constitutively active hemichannels to promote necrotic cell death. PLOS ONE 7: e32531.

Chkourko HS, Guerrero-Serna G, Lin X, Darwish N, Pohlmann JR, Cook KE, Martens JR, Rothenberg E, Musa H, Delmar M. 2012. Remodeling of mechanical junctions and of microtubule-associated proteins accompany cardiac connexin43 lateralization. Heart Rhythm 9: 11331140 e1136.

Churko JM, Shao Q, Gong XQ, Swoboda KJ, Bai D, Sampson J, Laird DW. 2011. Human dermal fibroblasts derived from oculodentodigital dysplasia patients suggest that patients may have wound-healing defects. Hum Mutat 32: 456-466.

Cina C, Bechberger JF, Ozog MA, Naus CC. 2007. Expression of connexins in embryonic mouse neocortical development. J Comp Neurol 504: 298-313.

Cina C, Maass K, Theis M, Willecke K, Bechberger JF, Naus CC. 2009. Involvement of the cytoplasmic C-terminal domain of connexin 43 in neuronal migration. J Neurosci 29: 2009-2021.
Cohen-Salmon M, Ott T, Michel V, Hardelin JP, Perfettini I, Eybalin M, Wu T, Marcus DC, Wangemann P, Willecke $\mathrm{K}$, et al. 2002. Targeted ablation of connexin 26 in the inner ear epithelial gap junction network causes hearing impairment and cell death. Curr Biol 12: 1106-1111.

Crow DS, Kurata WE, Lau AF. 1992. Phosphorylation of connexin 43 in cells containing mutant src oncogenes. Oncogene 7: 999-1003.

Danik SB, Liu F, Zhang J, Suk HJ, Morley GE, Fishman GE, Gutstein DE. 2004. Modulation of cardiac gap junction expression and arrhythmic susceptibility. Circ Res 95: 1035-1041.

Deans MR, Gibson JR, Sellitto C, Connors BW, Paul DL. 2001. Synchronous activity of inhibitory networks in neocortex requires electrical synapses containing connexin36. Neuron 31: 477-485.

De Bock M, Culot M, Wang N, Bol M, Decrock E, De Vuyst E, da Costa A, Dauwe I, Vinken M, Simon AM, et al. 2011. Connexin channels provide a target to manipulate brain endothelial calcium dynamics and blood-brain barrier permeability. J Cereb Blood Flow Metab 31: 1942-1957.

De Bock M, Kerrebrouck M, Wang N, Leybaert L. 2013a. Neurological manifestations of oculodentodigital dysplasia: A Cx43 channelopathy of the central nervous system? Front Pharmacol 4: 120.

De Bock M, Wang N, Decrock E, Bol M, Gadicherla AK, Culot M, Cecchelli R, Bultynck G, Leybaert L. 2013b. Endothelial calcium dynamics, connexin channels and blood-brain barrier function. Prog Neurobiol 108: 1-20.

De Bock M, Vandenbroucke RE, Decrock E, Culot M, Cecchelli R, Leybaert L. 2014. A new angle on blood-CNS interfaces: A role for connexins? FEBS Lett 588: 12591270.

Decrock E, De Bock M, Wang N, Bultynck G, Giaume C, Naus CC, Green CR, Leybaert L. 2015. Connexin and pannexin signaling pathways, an architectural blueprint for CNS physiology and pathology? Cell Mol Life Sci 72: 2823-2851.

Dere E, Zheng-Fischhofer Q, Viggiano D, Gironi Carnevale UA, Ruocco LA, Zlomuzica A, Schnichels M, Willecke K, Huston JP, Sadile AG. 2008. Connexin31.1 deficiency in the mouse impairs object memory and modulates openfield exploration, acetylcholine esterase levels in the striatum, and cAMP response element-binding protein levels in the striatum and piriform cortex. Neuroscience 153: 396-405.

De Zeeuw CI, Chorev E, Devor A, Manor Y, Van Der Giessen RS, De Jeu MT, Hoogenraad CC, Bijman J, Ruigrok TJ, French P, et al. 2003. Deformation of network connectivity in the inferior olive of connexin 36-deficient mice is compensated by morphological and electrophysiological changes at the single neuron level. J Neurosci 23: 47004711.

Di WL, Rugg EL, Leigh IM, Kelsell DP. 2001. Multiple epidermal connexins are expressed in different keratinocyte subpopulations including connexin 31. J Invest Dermatol 117: 958-964.

Dobrenis K, Chang HY, Pina-Benabou MH, Woodroffe A, Lee SC, Rozental R, Spray DC, Scemes E. 2005. Human and mouse microglia express connexin 36 , and functional gap junctions are formed between rodent microglia and neurons. J Neurosci Res 82: 306-315. 
Dobrowolski R, Sasse P, Schrickel JW, Watkins M, Kim JS, Rackauskas M, Troatz C, Ghanem A, Tiemann K, Degen J, et al. 2008. The conditional connexin43G138R mouse mutant represents a new model of hereditary oculodentodigital dysplasia in humans. Hum Mol Genet 17: 539554.

Elias LA, Wang DD, Kriegstein AR. 2007. Gap junction adhesion is necessary for radial migration in the neocortex. Nature 448: 901-907.

Elsholz F, Harteneck C, Muller W, Friedland K. 2014. Calcium-A central regulator of keratinocyte differentiation in health and disease. Eur J Dermatol 24: 650-661.

Esseltine JL, Shao Q, Huang T, Kelly JJ, Sampson J, Laird DW. 2015. Manipulating Cx43 expression triggers gene reprogramming events in dermal fibroblasts from oculodentodigital dysplasia patients. Biochem J 472: 55-69.

Essenfelder GM, Bruzzone R, Lamartine J, Charollais A, Blanchet-Bardon C, Barbe MT, Meda P, Waksman G. 2004. Connexin 30 mutations responsible for hidrotic ectodermal dysplasia cause abnormal hemichannel activity. Hum Mol Genet 13: 1703-1714.

Eugenin EA, Eckardt D, Theis M, Willecke K, Bennett MV, Saez JC. 2001. Microglia at brain stab wounds express connexin 43 and in vitro form functional gap junctions after treatment with interferon-gamma and tumor necrosis factor- $\alpha$. Proc Natl Acad Sci 98: 4190-4195.

Ezan P, Andre P, Cisternino S, Saubamea B, Boulay AC, Doutremer S, Thomas MA, Quenech'du N, Giaume C, Cohen-Salmon M. 2012. Deletion of astroglial connexins weakens the blood-brain barrier. J Cereb Blood Flow Metab 32: 1457-1467.

Firek L, Weingart R. 1995. Modification of gap junction conductance by divalent cations and protons in neonatal rat heart cells. J Mol Cell Cardiol 27: 1633-1643.

Flenniken AM, Osborne LR, Anderson N, Ciliberti N, Fleming C, Gittens JE, Gong XQ, Kelsey LB, Lounsbury C, Moreno L, et al. 2005. A Gjal missense mutation in a mouse model of oculodentodigital dysplasia. Development 132: 4375-4386.

Fluri GS, Rudisuli A, Willi M, Rohr S, Weingart R. 1990. Effects of arachidonic acid on the gap junctions of neonatal rat heart cells. Pflugers Arch 417: 149-156.

Forge A, Becker D, Casalotti S, Edwards J, Marziano N, Nevill G. 2003. Gap junctions in the inner ear: Comparison of distribution patterns in different vertebrates and assessement of connexin composition in mammals. $J$ Comp Neurol 467: 207-231.

Francis R, Xu X, Park H, Wei CJ, Chang S, Chatterjee B, Lo C 2011. Connexin 43 modulates cell polarity and directional cell migration by regulating microtubule dynamics. PLoS ONE 6: e26379.

Freitas-Andrade M, Naus CC. 2016. Astrocytes in neuroprotection and neurodegeneration: The role of con nexin43 and pannexin1. Neuroscience 323: 207-221.

Froger N, Orellana JA, Calvo CF, Amigou E, Kozoriz MG, Naus CC, Saez JC, Giaume C. 2010. Inhibition of cytokine-induced connexin 43 hemichannel activity in astrocytes is neuroprotective. Mol Cell Neurosci 45: 37-46.

Fushiki S, Perez Velazquez JL, Zhang L, Bechberger JF, Carlen PL, Naus CC. 2003. Changes in neuronal migration in neocortex of connexin 43 null mutant mice. J Neuropathol Exp Neurol 62: 304-314.
Gajardo-Gomez R, Labra VC, Orellana JA. 2016. Connexins and pannexins: New insights into microglial functions and dysfunctions. Front Mol Neurosci 9: 86.

Garcia-Dorado D, Inserte J, Ruiz-Meana M, Gonzalez MA, Solares J, Julia M, Barrabes JA, Soler-Soler J. 1997. Gap junction uncoupler heptanol prevents cell-to-cell progression of hypercontracture and limits necrosis during myocardial reperfusion. Circulation 96: 3579-3586.

Garcia IE, Maripillan J, Jara O, Ceriani R, Palacios-Munoz A, Ramachandran J, Olivero P, Perez-Acle T, Gonzalez C, Saez JC, et al. 2015. Keratitis-ichthyosis-deafness syndrome-associated Cx26 mutants produce nonfunctional gap junctions but hyperactive hemichannels when co-expressed with wild type Cx43. J Invest Dermatol 135: 1338 1347.

Gerido DA, DeRosa AM, Richard G, White TW. 2007. Aberrant hemichannel properties of $\mathrm{Cx} 26$ mutations causing skin disease and deafness. Am J Physiol Cell Physiol 293: C337-C345.

Giaume C, Koulakoff A, Roux L, Holcman D, Rouach N. 2010. Astroglial networks: A step further in neuroglial and gliovascular interactions. Nat Rev Neurosci 11: 87-99.

Gilliam A, Williams ML. 2002. Fatal septicemia in an infant with keratitis, ichthyosis, and deafness (KID) syndrome. Pediatr Dermatol 19: 232-236.

Gollob MH, Jones DL, Krahn AD, Danis L, Gong XQ, Shao Q, Liu X, Veinot JP, Tang AS, Stewart AF, et al. 2006. Somatic mutations in the connexin 40 gene (GJA5) in atrial fibrillation. N Engl J Med 354: 2677-2688.

Griffith AJ, Yang Y, Pryor SP, Park HJ, Jabs EW, Nadol JB Jr, Russell LJ, Wasserman DI, Richard G, Adams JC, et al. 2006. Cochleosaccular dysplasia associated with a connexin 26 mutation in keratitis-ichthyosis-deafness syndrome. Laryngoscope 116: 1404-1408.

Guldenagel M, Ammermuller J, Feigenspan A, Teubner B, Degen J, Sohl G, Willecke K, Weiler R. 2001. Visual transmission deficits in mice with targeted disruption of the gap junction gene connexin36. J Neurosci 21: 6036-6044.

Hagendorff A, Schumacher B, Kirchhoff S, Luderitz B, Willecke K. 1999. Conduction disturbances and increased atrial vulnerability in connexin 40-deficient mice analyzed by transesophageal stimulation. Circulation 99: 15081515.

Haugan K, Marcussen N, Kjolbye AL, Nielsen MS, Hennan JK, Petersen JS. 2006. Treatment with the gap junction modifier rotigaptide (ZP123) reduces infarct size in rats with chronic myocardial infarction. J Cardiovasc Pharmacol 47: 236-242.

Hennan JK, Swillo RE, Morgan GA, Keith JC Jr, Schaub RG, Smith RP, Feldman HS, Haugan K, Kantrowitz J, Wang PJ, et al. 2006. Rotigaptide (ZP123) prevents spontaneous ventricular arrhythmias and reduces infarct size during myocardial ischemia/reperfusion injury in open-chest dogs. J Pharmacol Exp Ther 317: 236-243.

Hofgaard JP, Banach K, Mollerup S, Jorgensen HK, Olesen SP, Holstein-Rathlou NH, Nielsen NS. 2008. Phosphatidylinositol-bisphosphate regulates intercellular coupling in cardiac myocytes. Pflugers Arch 457: 303-313.

Hormuzdi SG, Pais I, LeBeau FE, Towers SK, Rozov A, Buhl EH, Whittington MA, Monyer H. 2001. Impaired electrical signaling disrupts gamma frequency oscillations in connexin 36-deficient mice. Neuron 31: 487-495. 
M. Delmar et al.

Huang T, Shao Q, MacDonald A, Xin L, Lorentz R, Bai D, Laird DW. 2013. Autosomal recessive GJA1 (Cx43) gene mutations cause oculodentodigital dysplasia by distinct mechanisms. J Cell Sci 126: 2857-2866.

Ito A, Katoh F, Kataoka TR, Okada M, Tsubota N, Asada H, Yoshikawa K, Maeda S, Kitamura Y, Yamasaki H, et al. 2000. A role for heterologous gap junctions between melanoma and endothelial cells in metastasis. J Clin Invest 105: 1189-1197.

Janecke AR, Hennies HC, Gunther B, Gansl G, Smolle J, Messmer EM, Utermann G, Rittinger O. 2005. GJB2 mutations in keratitis-ichthyosis-deafness syndrome including its fatal form. Am J Med Genet A 133A: 128-131.

Jansen JA, Noorman M, Musa H, Stein M, de Jong S, van der Nagel R, Hund TJ, Mohler PJ, Vos MA, van Veen TA, et al. 2012. Reduced heterogeneous expression of $\mathrm{Cx} 43$ results in decreased Nav1.5 expression and reduced sodium current that accounts for arrhythmia vulnerability in conditional Cx43 knockout mice. Heart Rhythm 9: 600-607.

Kalcheva N, Qu J, Sandeep N, Garcia L, Zhang J, Wang Z, Lampe PD, Suadicani SO, Spray DC, Fishman GI. 2007. Gap junction remodeling and cardiac arrhythmogenesis in a murine model of oculodentodigital dysplasia. Proc Natl Acad Sci 104: 20512-20516.

Kelly JJ, Simek J, Laird DW. 2015. Mechanisms linking connexin mutations to human diseases. Cell Tissue Res 360: 701-721.

King TJ, Lampe PD. 2004a. The gap junction protein connexin 32 is a mouse lung tumor suppressor. Cancer Res 64 7191-7196.

King TJ, Lampe PD. 2004b. Mice deficient for the gap junction protein connexin 32 exhibit increased radiation-induced tumorigenesis associated with elevated mitogenactivated protein kinase (p44/Erk1, p42/Erk2) activation. Carcinogenesis 25: 669-680.

Kleber AG, Riegger CB, Janse MJ. 1987. Electrical uncoupling and increase of extracellular resistance after induction of ischemia in isolated, arterially perfused rabbit papillary muscle. Circ Res 61: 271-279.

Kleopa KA, Sargiannidou I. 2015. Connexins, gap junctions and peripheral neuropathy. Neurosci Lett 596: 27-32.

Kleopa KA, Abrams CK, Scherer SS. 2012. How do mutations in GJB1 cause X-linked Charcot-Marie-Tooth disease? Brain Res 1487: 198-205.

Kostin S, Rieger M, Dammer S, Hein S, Richter M, Klovekorn WP, Bauer EP, Schaper J. 2003. Gap junction remodeling and altered connexin43 expression in the failing human heart. Mol Cell Biochem 242: 135-144.

Kostin S, Dammer S, Hein S, Klovekorn WP, Bauer EP, Schaper J. 2004. Connexin 43 expression and distribution in compensated and decompensated cardiac hypertrophy in patients with aortic stenosis. Cardiovasc Res 62: 426436.

Kreuzberg MM, Deuchars J, Weiss E, Schober A, Sonntag S, Wellershaus K, Draguhn A, Willecke K. 2008. Expression of connexin30.2 in interneurons of the central nervous system in the mouse. Mol Cell Neurosci 37: 119-134.

Krutovskikh VA, Troyanovsky SM, Piccoli C, Tsuda H, Asamoto M, Yamasaki H. 2000. Differential effect of subcellular localization of communication impairing gap junction protein connexin 43 on tumor cell growth in vivo. Oncogene 19: 505-513.
Kudo T, Kure S, Ikeda K, Xia AP, Katori Y, Suzuki M, Kojima K, Ichinohe A, Suzuki Y, Aoki Y, et al. 2003. Transgenic expression of a dominant-negative connexin 26 causes degeneration of the organ of Corti and non-syndromic deafness. Hum Mol Genet 12: 995-1004.

Labarthe MP, Bosco D, Saurat JH, Meda P, Salomon D. 1998. Upregulation of connexin 26 between keratinocytes of psoriatic lesions. J Invest Dermatol 111: 72-76.

Laird DW. 2014. Syndromic and non-syndromic diseaselinked Cx43 mutations. FEBS Lett 588: 1339-1348.

Lampe PD, Cooper CD, King TJ, Burt JM. 2006. Analysis of connexin 43 phosphorylated at S325, S328 and S330 in normoxic and ischemic heart. J Cell Sci 119: 3435-3442.

Lautermann J, ten Cate WJ, Altenhoff P, Grummer R, Traub O, Frank H, Jahnke K, Winterhager E. 1998. Expression of the gap-junction connexins 26 and 30 in the rat cochlea. Cell Tissue Res 294: 415-420.

Lee JR, White TW. 2009. Connexin-26 mutations in deafness and skin disease. Expert Rev Mol Med 11: e35.

Lee JR, Derosa AM, White TW. 2009. Connexin mutations causing skin disease and deafness increase hemichannel activity and cell death when expressed in Xenopus oocytes. J Invest Dermatol 129: 870-878.

Leo-Macias A, Agullo-Pascual E, Delmar M. 2016a. The cardiac connexome: Non-canonical functions of connexin 43 and their role in cardiac arrhythmias. Semin Cell Dev Biol 50: 13-21.

Leo-Macias A, Agullo-Pascual E, Sanchez-Alonso JL, Keegan S, Lin X, Arcos T, Feng Xia L, Korchev YE, Gorelik J, Fenyo D, et al. 2016b. Nanoscale visualization of functional adhesion/excitability nodes at the intercalated disc. Nat Commun 7: 10342.

Levit NA, Mese G, Basaly MG, White TW. 2011. Pathological hemichannels associated with human Cx26 mutations causing Keratitis-Ichthyosis-Deafness syndrome. Biochim Biophys Acta 1818: 2014-2019.

Lewandowski R, Procida K, Vaidyanathan R, Coombs W, Jalife J, Nielsen MS, Taffet SM, Delmar M. 2008. RXPE: A connexin43-binding peptide that prevents action potential propagation block. Circ Res 103: 519-526.

Li X, Heinzel FR, Boengler K, Schulz R, Heusch G. 2004. Role of connexin 43 in ischemic preconditioning does not involve intercellular communication through gap junctions. J Mol Cell Cardiol 36: 161-163.

Li X, Kamasawa N, Ciolofan C, Olson CO, Lu S, Davidson KG, Yasumura T, Shigemoto R, Rash JE, Nagy JI. 2008. Connexin45-containing neuronal gap junctions in rodent retina also contain connexin 36 in both apposing hemiplaques, forming bihomotypic gap junctions, with scaffolding contributed by zonula occludens-1. J Neurosci 28: 9769-9789.

Liang C, Zhu Y, Zong L, Lu GJ, Zhao HB. 2012. Cell degeneration is not a primary causer for Connexin26 (GJB2) deficiency associated hearing loss. Neurosci Lett 528: 3641.

Lilly E, Sellitto C, Milstone LM, White TW. 2016. Connexin channels in congenital skin disorders. Semin Cell Dev Biol 50: 4-12.

Liu YP, Zhao HB. 2008. Cellular characterization of connexin 26 and connnexin 30 expression in the cochlear lateral wall. Cell Tissue Res 333: 395-403. 
Loddenkemper T, Grote K, Evers S, Oelerich M, Stogbauer F 2002. Neurological manifestations of the oculodentodigital dysplasia syndrome. J Neurol 249: 584-595.

Loewenstein WR, Kanno Y. 1966. Intercellular communication and the control of tissue growth: Lack of communication between cancer cells. Nature 209: 1248-1249.

Long MA, Deans MR, Paul DL, Connors BW. 2002. Rhythmicity without synchrony in the electrically uncoupled inferior olive. J Neurosci 22: 10898-10905.

Lubkemeier I, Andrie R, Lickfett L, Bosen F, Stockigt F, Dobrowolski R, Draffehn AM, Fregeac J, Schultze JL, Bukauskas FF, et al. 2013a. The connexin40A96S mutation from a patient with atrial fibrillation causes decreased atrial conduction velocities and sustained episodes of induced atrial fibrillation in mice. J Mol Cell Cardiol 65: 1932.

Lubkemeier I, Requardt RP, Lin X, Sasse P, Andrie R, Schrickel JW, Chkourko H, Bukauskas FF, Kim JS, Frank $\mathrm{M}$, et al. 2013b. Deletion of the last five C-terminal amino acid residues of connexin43 leads to lethal ventricular arrhythmias in mice without affecting coupling via gap junction channels. Basic Res Cardiol 108: 348.

Lucke T, Choudhry R, Thom R, Selmer IS, Burden AD, Hodgins MB. 1999. Upregulation of connexin 26 is a feature of keratinocyte differentiation in hyperproliferative epidermis, vaginal epithelium, and buccal epithelium. J Invest Dermatol 112: 354-361.

Maass K, Chase SE, Lin X, Delmar M. 2009. Cx43 CT domain influences infarct size and susceptibility to ventricular tachyarrhythmias in acute myocardial infarction. Cardiovasc Res 84: 361-367.

Maeda Y, Fukushima K, Kawasaki A, Nishizaki K, Smith RJ. 2007. Cochlear expression of a dominant-negative $G J B 2_{\mathrm{R} 75 \mathrm{~W}}$ construct delivered through the round window membrane in mice. Neurosci Res 58: 250-254.

Maezawa I, Jin W. 2010. Rett syndrome microglia damage dendrites and synapses by the elevated release of glutamate. J Neurosci 30: 5346-5356.

Majumder P, Crispino G, Rodriguez L, Ciubotaru CD, Anselmi F, Piazza V, Bortolozzi M, Mammano F. 2010. ATPmediated cell-cell signaling in the organ of Corti: The role of connexin channels. Purinergic Signal 6: 167-187.

McLachlan E, Shao Q, Wang HL, Langlois S, Laird DW. 2006. Connexins act as tumor suppressors in three-dimensional mammary cell organoids by regulating differentiation and angiogenesis. Cancer Res 66: 9886-9894.

Mei X, Ezan P, Giaume C, Koulakoff A. 2010. Astroglial connexin immunoreactivity is specifically altered at $\beta$ amyloid plaques in $\beta$-amyloid precursor protein/presenilin1 mice. Neuroscience 171: 92-105.

Menichella DM, Goodenough DA, Sirkowski E, Scherer SS, Paul DL. 2003. Connexins are critical for normal myelination in the CNS. J Neurosci 23: 5963-5973.

Menichella DM, Majdan M, Awatramani R, Goodenough DA, Sirkowski E, Scherer SS, Paul DL. 2006. Genetic and physiological evidence that oligodendrocyte gap junctions contribute to spatial buffering of potassium released during neuronal activity. J Neurosci 26: 1098410991.

Mese G, Valiunas V, Brink PR, White TW. 2008. Connexin 26 deafness associated mutations show altered per- meability to large cationic molecules. Am J Physiol Cell Physiol 295: C966-C974.

Mese G, Sellitto C, Li L, Wang HZ, Valiunas V, Richard G, Brink PR, White TW. 2011. The Cx26-G45E mutation displays increased hemichannel activity in a mouse model of the lethal form of keratitis-ichthyosis-deafness syndrome. Mol Biol Cell 22: 4776-4786.

Mesnil M. 2002. Connexins and cancer. Biol Cell 94: 493500.

Mhaske PV, Levit NA, Li L, Wang HZ, Lee JR, Shuja Z, Brink PR, White TW. 2013. The human Cx26-D50A and Cx26A88V mutations causing keratitis-ichthyosis-deafness syndrome display increased hemichannel activity. Am J Physiol Cell Physiol 304: C1150-C1158.

Mollerup S, Hofgaard JP, Braunstein TH, Kjenseth A, Leithe E, Rivedal E, Holstein-Rathlou NH, Nielsen MS. 2011. Norepinephrine inhibits intercellular coupling in rat cardiomyocytes by ubiquitination of connexin 43 gap junctions. Cell Commun Adhes 18: 57-65.

Moon Y, Choi SY, Kim K, Kim H, Sun W. 2010. Expression of connexin 29 and 32 in the penumbra region after traumatic brain injury of mice. Neuroreport 21: 1135-1139.

Morley GE, Taffet SM, Delmar M. 1996. Intramolecular interactions mediate $\mathrm{pH}$ regulation of connexin 43 channels. Biophys J 70: 1294-1302.

Morley GE, Vaidya D, Samie FH, Lo C, Delmar M, Jalife J. 1999. Characterization of conduction in the ventricles of normal and heterozygous $\mathrm{Cx} 43$ knockout mice using optical mapping. J Cardiovasc Electrophysiol 10: 1361-1375.

Nagy JI, Patel D, Ochalski PA, Stelmack GL. 1999. Connexin30 in rodent, cat and human brain: Selective expression in gray matter astrocytes, co-localization with connexin 43 at gap junctions and late developmental appearance. Neuroscience 88: 447-468.

Nagy JI, Li X, Rempel J, Stelmack G, Patel D, Staines WA, Yasumura T, Rash JE. 2001. Connexin26 in adult rodent central nervous system: Demonstration at astrocytic gap junctions and colocalization with connexin 30 and connexin43. J Comp Neurol 441: 302-323.

Naus CC, Laird DW. 2010. Implications and challenges of connexin connections to cancer. Nat Rev Cancer 10: 435441.

Naus CC, Elisevich K, Zhu D, Belliveau DJ, Del Maestro RF. 1992. In vivo growth of C6 glioma cells transfected with connexin 43 cDNA. Cancer Res 52: 4208-4213.

Nielsen MS, Axelsen LN, Sorgen PL, Verma V, Delmar M, Holstein-Rathlou NH. 2012. Gap junctions. Compr Physiol 2: 1981-2035.

Odermatt B, Wellershaus K, Wallraff A, Seifert G, Degen J, Euwens C, Fuss B, Bussow H, Schilling K, Steinhauser C, et al. 2003. Connexin 47 (Cx47)-deficient mice with enhanced green fluorescent protein reporter gene reveal predominant oligodendrocytic expression of $\mathrm{Cx} 47$ and display vacuolized myelin in the CNS. J Neurosci 23: 45494559.

Ohara T, Qu Z, Lee MH, Ohara K, Omichi C, Mandel WJ, Chen PS, Karagueuzian HS. 2002. Increased vulnerability to inducible atrial fibrillation caused by partial cellular uncoupling with heptanol. Am J Physiol Heart Circ Physiol 283: H1116-H1122. 
M. Delmar et al.

O'Quinn MP, Palatinus JA, Harris BS, Hewett KW, Gourdie RG. 2011. A peptide mimetic of the connexin 43 carboxyl terminus reduces gap junction remodeling and induced arrhythmia following ventricular injury. Circ Res 108: 704-715.

Ortolano S, Di Pasquale G, Crispino G, Anselmi F, Mammano F, Chiorini JA. 2008. Coordinated control of connexin 26 and connexin 30 at the regulatory and functional level in the inner ear. Proc Natl Acad Sci 105: 1877618781.

Pannasch U, Vargova L, Reingruber J, Ezan P, Holcman D, Giaume C, Sykova E, Rouach N. 2011. Astroglial networks scale synaptic activity and plasticity. Proc Natl Acad Sci 108: $8467-8472$.

Pannasch U, Freche D, Dallerac G, Ghezali G, Escartin C, Ezan P, Cohen-Salmon M, Benchenane K, Abudara V, Dufour A, et al. 2014. Connexin 30 sets synaptic strength by controlling astroglial synapse invasion. Nat Neurosci 17: $549-558$

Patuzzi R. 2011. Ion flow in stria vascularis and the production and regulation of cochlear endolymph and the endolymphatic potential. Hearing Res 277: 4-19.

Paznekas WA, Boyadjiev SA, Shapiro RE, Daniels O, Wollnik B, Keegan CE, Innis JW, Dinulos MB, Christian C Hannibal MC, et al. 2003. Connexin 43 (GJA1) mutations cause the pleiotropic phenotype of oculodentodigital dysplasia. Am J Hum Genet 72: 408-418.

Paznekas WA, Karczeski B, Vermeer S, Lowry RB, Delatyck M, Laurence F, Koivisto PA, Van Maldergem L, Boyadjiev SA, Bodurtha JN, et al. 2009. GJA1 mutations, variants, and connexin 43 dysfunction as it relates to the oculodentodigital dysplasia phenotype. Hum Mutat 30: 724-733.

Personius KE, Chang Q, Mentis GZ, O’Donovan MJ, BaliceGordon RJ. 2007. Reduced gap junctional coupling leads to uncorrelated motor neuron firing and precocious neuromuscular synapse elimination. Proc Natl Acad Sci 104: 11808-11813.

Peters NS, Coromilas J, Severs NJ, Wit AL. 1997. Disturbed connexin 43 gap junction distribution correlates with the location of reentrant circuits in the epicardial border zone of healing canine infarcts that cause ventricular tachycardia. Circulation 95: 988-996.

Plante I, Stewart MK, Barr K, Allan AL, Laird DW. 2011. Cx43 suppresses mammary tumor metastasis to the lung in a $\mathrm{Cx} 43$ mutant mouse model of human disease. Oncogene 30: 1681-1692.

Qu Y, Tang W, Zhou B, Ahmad S, Chang Q, Li X, Lin X. 2012. Early developmental expression of connexin26 in the cochlea contributes to its dominate functional role in the cochlear gap junctions. Biochem Biophys Res Commun 417: 245-250.

Ransom B, Giaume C. 2012. Gap junctions and hemichannels. In Neuroglia (Kettenmann H, Ransom BR), pp. 292305. Oxford University Press, New York.

Rash JE, Kamasawa N, Davidson KG, Yasumura T, Pereda AE, Nagy JI. 2012. Connexin composition in apposed gap junction hemiplaques revealed by matched double-replica freeze-fracture replica immunogold labeling. J Membr Biol 245: 333-344.

Rhett JM, Jourdan J, Gourdie RG. 2011. Connexin 43 connexon to gap junction transition is regulated by zonula occludens-1. Mol Biol Cell 22: 1516-1528.
Rhett JM, Ongstad EL, Jourdan J, Gourdie RG. 2012. Cx43 associates with $\mathrm{Na}_{\mathrm{v}} 1.5$ in the cardiomyocyte perinexus. $J$ Membr Biol 245: 411-422.

Rivas MV, Jarvis ED, Morisaki S, Carbonaro H, Gottlieb AB, Krueger JG. 1997. Identification of aberrantly regulated genes in diseased skin using the cDNA differential display technique. J Invest Dermatol 108: 188-194.

Rouan F, White TW, Brown N, Taylor AM, Lucke TW, Paul DL, Munro CS, Uitto J, Hodgins MB, Richard G. 2001. trans-dominant inhibition of connexin-43 by mutant connexin-26: Implications for dominant connexin disorders affecting epidermal differentiation. J Cell Sci 114: 2105-2113.

Salomon D, Masgrau E, Vischer S, Ullrich S, Dupont E, Sappino P, Saurat JH, Meda P. 1994. Topography of mammalian connexins in human skin. J Invest Dermatol 103: 240-247.

Sanchez HA, Verselis VK. 2014. Aberrant Cx26 hemichannels and Keratitis-Ichthyosis-Deafness Syndrome: Insights into syndromic hearing loss. Front Cell Neurosci 8: 354 .

Sanchez HA, Mese G, Srinivas M, White TW, Verselis VK. 2010. Differentially altered $\mathrm{Ca}^{2+}$ regulation and $\mathrm{Ca}^{2+}$ permeability in Cx26 hemichannels formed by the A40V and G45E mutations that cause keratitis ichthyosis deafness syndrome. J Gen Physiol 136: 47-62.

Sanchez HA, Villone K, Srinivas M, Verselis VK. 2013. The D50N mutation and syndromic deafness: Altered Cx26 hemichannel properties caused by effects on the pore and intersubunit interactions. J Gen Physiol 142: 3-22.

Sanchez HA, Bienkowski R, Slavi N, Srinivas M, Verselis VK. 2014. Altered inhibition of $\mathrm{Cx} 26$ hemichannels by $\mathrm{pH}$ and $\mathrm{Zn}^{2+}$ in the $\mathrm{A} 40 \mathrm{~V}$ mutation associated with keratitis-ichthyosis-deafness syndrome. J Biol Chem 289: 21519-21532.

Sanchez HA, Slavi N, Srinivas M, Verselis VK. 2016. Syndromic deafness mutations at Asn 14 differentially alter the open stability of Cx26 hemichannels. J Gen Physiol 148: $25-42$.

Scemes E, Spray DC. 2012. Extracellular $\mathrm{K}^{+}$and astrocyte signaling via connexin and pannexin channels. Neurochem Res 37: 2310-2316.

Schutz M, Scimemi P, Majumder P, De Siati RD, Crispino G, Rodriguez L, Bortolozzi M, Santarelli R, Seydel A, Sonntag S, et al. 2010. The human deafness-associated connexin 30 T5M mutation causes mild hearing loss and reduces biochemical coupling among cochlear non-sensory cells in knock-in mice. Hum Mol Genet 19: 47594773.

Schutz M, Auth T, Gehrt A, Bosen F, Korber I, Strenzke N, Moser T, Willecke K. 2011. The connexin26 S17F mouse mutant represents a model for the human hereditary keratitis-ichthyosis-deafness syndrome. Hum Mol Genet 20: 28-39.

Schwanke U, Konietzka I, Duschin A, Li X, Schulz R, Heusch G. 2002. No ischemic preconditioning in heterozygous connexin43-deficient mice. Am J Physiol Heart Circ Physiol 283: H1740-H1742.

Shibayama J, Paznekas W, Seki S, Taffet S, Jabs EW, Delmar M, Musa H. 2005. Functional characterization of connexin 43 mutations found in patients with oculodentodigital dysplasia. Circ Res 96: e83-e91. 
Shuja Z, Li L, Gupta S, Mese G, White TW. 2016. Connexin26 mutations causing palmoplantar keratoderma and deafness interact with connexin 43 , modifying gap junction and hemichannel properties. J Invest Dermatol 136: $225-235$.

Sinner MF, Tucker NR, Lunetta KL, Ozaki K, Smith JG, Trompet S, Bis JC, Lin H, Chung MK, Nielsen JB, et al. 2014. Integrating genetic, transcriptional, and functional analyses to identify 5 novel genes for atrial fibrillation. Circulation 130: 1225-1235.

Skyschally A, Walter B, Schultz Hansen R, Heusch G. 2013. The antiarrhythmic dipeptide ZP1609 (danegaptide) when given at reperfusion reduces myocardial infarct size in pigs. Naunyn Schmiedebergs Arch Pharmacol 386: 383-391.

Smith WTt, Fleet WF, Johnson TA, Engle CL, Cascio WE. 1995. The Ib phase of ventricular arrhythmias in ischemic in situ porcine heart is related to changes in cell-to-cell electrical coupling. Circulation 92: 3051-3060.

Sperelakis N. 2002. An electric field mechanism for transmission of excitation between myocardial cells. Circ Res 91: 985-987.

Stein M, van Veen TA, Remme CA, Boulaksil M, Noorman $M$, van Stuijvenberg $L$, van der Nagel R, Bezzina $C R$, Hauer RN, de Bakker JM, et al. 2009. Combined reduction of intercellular coupling and membrane excitability differentially affects transverse and longitudinal cardiac conduction. Cardiovasc Res 83: 52-60.

Stong BC, Chang Q, Ahmad S, Lin X. 2006. A novel mechanism for connexin 26 mutation linked deafness: Cell death caused by leaky gap junction hemichannels. Laryngoscope 116: 2205-2210.

Sun Y, Tang W, Chang Q, Wang Y, Kong W, Lin X. 2009 Connexin30 null and conditional connexin26 null mice display distinct pattern and time course of cellular degeneration in the cochlea. J Comp Neurol 516: 569-579.

Takeuchi H, Jin S, Wang J, Zhang G, Kawanokuchi J, Kuno R, Sonobe Y, Mizuno T, Suzumura A. 2006. Tumor necrosis factor- $\alpha$ induces neurotoxicity via glutamate release from hemichannels of activated microglia in an autocrine manner. J Biol Chem 281: 21362-21368.

Temme A, Buchmann A, Gabriel HD, Nelles E, Schwarz M, Willecke K. 1997. High incidence of spontaneous and chemically induced liver tumors in mice deficient for connexin32. Curr Biol 7: 713-716.

Terrinoni A, Codispoti A, Serra V, Didona B, Bruno E, Nistico R, Giustizieri M, Alessandrini M, Campione E, Melino G. 2010. Connexin 26 (GJB2) mutations, causing KID Syndrome, are associated with cell death due to calcium gating deregulation. Biochem Biophys Res Commun 394: 909-914.

Teubner B, Michel V, Pesch J, Lautermann J, Cohen-Salmon M, Sohl G, Jahnke K, Winterhager E, Herberhold C, Hardelin JP, et al. 2003. Connexin30 (Gjb6)-deficiency causes severe hearing impairment and lack of endocochlear potential. Hum Mol Genet 12: 13-21.

Theodoric N, Bechberger JF, Naus CC, Sin WC. 2012. Role of gap junction protein connexin 43 in astrogliosis induced by brain injury. PLoS ONE 7: e47311.

Uhlenberg B, Schuelke M, Ruschendorf F, Ruf N, Kaindl AM, Henneke M, Thiele H, Stoltenburg-Didinger G Aksu F, Topaloglu H, et al. 2004. Mutations in the gene encoding gap junction protein $\alpha 12$ (connexin 46.6) cause Pelizaeus-Merzbacher-like disease. Am J Hum Genet 75: 251-260.

Veeraraghavan R, Salama ME, Poelzing S. 2012. Interstitial volume modulates the conduction velocity-gap junction relationship. Am J Physiol Heart Circ Physiol 302: H278H286.

Venance L, Rozov A, Blatow M, Burnashev N, Feldmeyer D, Monyer H. 2000. Connexin expression in electrically coupled postnatal rat brain neurons. Proc Natl Acad Sci 97: 10260-10265.

Verheule S, van Batenburg CA, Coenjaerts FE, Kirchhoff S, Willecke K, Jongsma HJ. 1999. Cardiac conduction abnormalities in mice lacking the gap junction protein connexin40. J Cardiovasc Electrophysiol 10: 1380-1389.

Wallraff A, Kohling R, Heinemann U, Theis M, Willecke K, Steinhauser C. 2006. The impact of astrocytic gap junctional coupling on potassium buffering in the hippocampus. J Neurosci 26: 5438-5447.

Wang Y, Chang Q, Tang W, Sun Y, Zhou B, Li H, Lin X. 2009. Targeted connexin 26 ablation arrests postnatal development of the organ of Corti. Biochem Biophys Res Commun 385: 33-37.

Wang H, Cao X, Lin Z, Lee M, Jia X, Ren Y, Dai L, Guan L, Zhang J, Lin X, et al. 2015. Exome sequencing reveals mutation in GJA1 as a cause of keratoderma-hypotrichosis-leukonychia totalis syndrome. Hum Mol Genet 24: 243-250

Wangemann P. 2006. Supporting sensory transduction: Cochlear fluid homeostasis and the endocochlear potential. J Physiol 576: 11-21.

Wasseff SK, Scherer SS. 2014. Activated microglia do not form functional gap junctions in vivo. J Neuroimmunol 269: 90-93.

Wojtczak J. 1979. Contractures and increase in internal longitudinal resistance of cow ventricular muscle induced by hypoxia. Circ Res 44: 88-95.

Xing D, Kjolbye AL, Nielsen MS, Petersen JS, Harlow KW, Holstein-Rathlou NH, Martins JB. 2003. ZP123 increases gap junctional conductance and prevents reentrant ventricular tachycardia during myocardial ischemia in open chest dogs. J Cardiovasc Electrophysiol 14: 510-520.

Xu J, Nicholson BJ. 2013. The role of connexins in ear and skin physiology-Functional insights from diseaseassociated mutations. Biochim Biophys Acta 1828: 167178.

Yamasaki H, Mesnil M, Omori Y, Mironov N, Krutovskikh V. 1995. Intercellular communication and carcinogenesis. Mutat Res 33: 181-188.

Yang J, Qin G, Luo M, Chen J, Zhang Q, Li L, Pan L, Qin S. 2015. Reciprocal positive regulation between Cx26 and PI3K/Akt pathway confers acquired gefitinib resistance in NSCLC cells via GJIC-independent induction of EMT. Cell Death Dis 6: e1829.

Yu M, Zhang C, Li L, Dong S, Zhang N, Tong X. 2014. Cx43 reverses the resistance of A549 lung adenocarcinoma cells to cisplatin by inhibiting EMT. Oncol Rep 31: 2751-2758. 


\section{Delmar et al.}

Zdebik AA, Wangemann P, Jentsch TJ. 2009. Potassium ion movement in the inner ear: Insights from genetic disease and mouse models. Physiology 24: 307-316.

Zhang Y, Tang W, Ahmad S, Sipp JA, Chen P, Lin X. 2005. Gap junction-mediated intercellular biochemical coupling in cochlear supporting cells is required for normal cochlear functions. Proc Natl Acad Sci 102: 1520115206.

Zhang J, O'Carroll SJ, Henare K, Ching LM, Ormonde S, Nicholson LF, Danesh-Meyer HV, Green CR. 2014. Connexin hemichannel induced vascular leak suggests a new paradigm for cancer therapy. FEBS Lett 588: 13651371.
Zhang A, Hitomi M, Bar-Shain N, Dalimov Z, Ellis L, Velpula KK, Fraizer GC, Gourdie RG, Lathia JD. 2015. Connexin 43 expression is associated with increased malignancy in prostate cancer cell lines and functions to promote migration. Oncotarget 6: 11640-11651.

Zhao HB, Yu N. 2006. Distinct and gradient distributions of connexin 26 and connexin30 in the cochlear sensory epithelium of guinea pigs. J Comp Neurol 499: 506518.

Zhu D, Caveney S, Kidder GM, Naus CC. 1991. Transfection of C6 glioma cells with connexin 43 cDNA: Analysis of expression, intercellular coupling, and cell proliferation. Proc Natl Acad Sci 88: 1883-1887. 


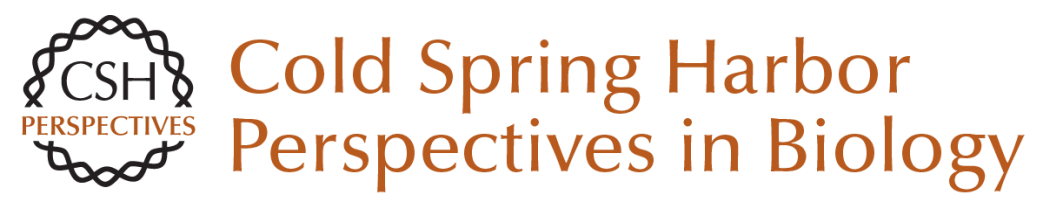

\section{Connexins and Disease}

Mario Delmar, Dale W. Laird, Christian C. Naus, Morten S. Nielsen, Vytautas K. Verselis and Thomas W. White

Cold Spring Harb Perspect Biol 2018; doi: 10.1101/cshperspect.a029348 originally published online August 4, 2017

Subject Collection Cell-Cell Junctions

Vascular Endothelial (VE)-Cadherin, Endothelial

Adherens Junctions, and Vascular Disease Maria Grazia Lampugnani, Elisabetta Dejana and Costanza Giampietro

Adherens Junctions and Desmosomes Coordinate Mechanics and Signaling to Orchestrate Tissue Morphogenesis and Function: An Evolutionary Perspective Matthias Rübsam, Joshua A. Broussard, Sara A. Wickström, et al.

Cell-Cell Contact and Receptor Tyrosine Kinase Signaling Christine Chiasson-MacKenzie and Andrea I. McClatchey

Hold Me, but Not Too Tight--Endothelial Cell-Cell Junctions in Angiogenesis Anna Szymborska and Holger Gerhardt

Connexins and Disease

Mario Delmar, Dale W. Laird, Christian C. Naus, et al.

Cell Junctions in Hippo Signaling

Ruchan Karaman and Georg Halder
Signaling by Small GTPases at Cell-Cell Junctions: Protein Interactions Building Control and Networks Vania Braga

Making Connections: Guidance Cues and Receptors at Nonneural Cell-Cell Junctions Ian V. Beamish, Lindsay Hinck and Timothy E. Kennedy

The Cadherin Superfamily in Neural Circuit Assembly James $D$. Jontes

Mechanosensing and Mechanotransduction at Cell-Cell Junctions Alpha S. Yap, Kinga Duszyc and Virgile Viasnoff

Beyond Cell-Cell Adhesion: Sensational

Cadherins for Hearing and Balance Avinash Jaiganesh, Yoshie Narui, Raul Araya-Secchi, et al.

Cell-Cell Junctions Organize Structural and Signaling Networks Miguel A. Garcia, W. James Nelson and Natalie Chavez

For additional articles in this collection, see http://cshperspectives.cshlp.org/cgi/collection/

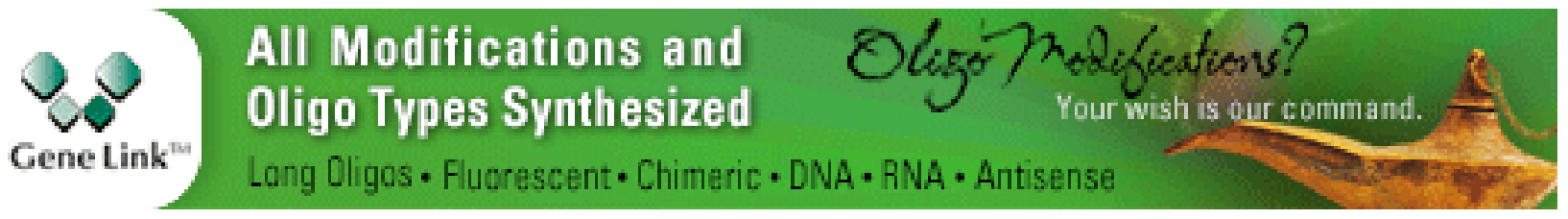

Copyright @ 2018 Cold Spring Harbor Laboratory Press; all rights reserved 
Loss of E-Cadherin-Dependent Cell-Cell Adhesion and the Development and Progression of Cancer Heather C. Bruner and Patrick W.B. Derksen

Desmosomes and Intermediate Filaments: Their Consequences for Tissue Mechanics

Mechthild Hatzfeld, René Keil and Thomas M. Magin
Cell Biology of Tight Junction Barrier Regulation and Mucosal Disease

Aaron Buckley and Jerrold R. Turner

Integration of Cadherin Adhesion and

Cytoskeleton at Adherens Junctions

René Marc Mège and Noboru Ishiyama

For additional articles in this collection, see http://cshperspectives.cshlp.org/cgi/collection/

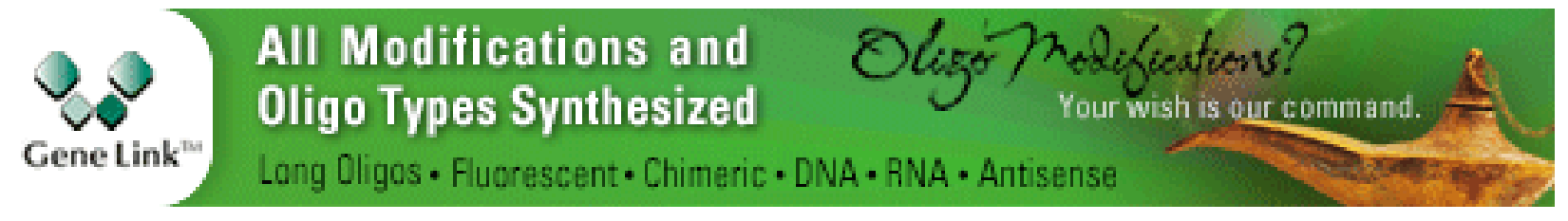

Copyright @ 2018 Cold Spring Harbor Laboratory Press; all rights reserved 